\title{
MANIFESTATION OF SOCIETAL ATTITUDE TOWARDS THE SOCIAL WORKER'S PROFESSION IN LITHUANIA AND THE UKRAINE
}

\author{
Virginija Nemeikšienè \\ Šiauliai State College, Lithuania \\ Kristina Rūdytè \\ Šiauliai University, Lithuania
}

\begin{abstract}
The paper focuses on the issues of societal attitude towards the social worker's profession. Aiming to reveal the societal attitude towards manifestation of the social worker's profession in Lithuania and the Ukraine, a quantitative research method has been chosen, using a semi-standardised questionnaire. The research data analysis employed a non-parametric statistical method - Kruskal-Wallis test. The hypothesis raised at the beginning of the research has been partly proven: it is likely that society has no clear vision on what are the characteristics of the content of professional activities of a social worker. The answers of the respondents $(N=784)$ suggest that they cannot exactly say what social work is; but understand where and with what kinds of people's groups the staff can work. They do not single out professional competences; however, they name the knowledge, abilities which are required for a social worker. They understand the values which are not attributed to general values but rather particularly oriented to a client, and know real material condition of a social worker, i.e. that this job is low paid.
\end{abstract}

Keywords: social work, society attitude, professional competence of a social worker.

\section{Introduction}

Social work was not acknowledged as a profession at once. Like any other profession, the latter develops as a response to the demand for this profession, and uniqueness of this profession supposes that it is a social profession whose object is a man - an individual, a family, a group of people having difficulties or problems which should be solved. A social worker must feel the pulse of societal well-being, social integration, conditions to harmonious functioning of the man and environment; and, when the pulse becomes irregular, to provide social support meeting clients' (consumers' of services) needs. Largest endeavours have been focused for that purpose by social workers in the USA. This work was carried out on the voluntarily basis and much was contributed to give social work the status of a profession and further professionalization of this performance would continue (Kavaliauskienè, 2010). In Lithuania and the Ukraine, social work is not a new 
Nemeikšienè \& Rüdytè, 2018. Manifestation of Societal Attitude Towards the Social Worker's Profession in Lithuania and the Ukraine

social phenomenon; the profession of support to an individual has been developing and is being developed by an intensive shift of the social-educational paradigm, in a situation of social transformations; however, nowadays intensive professionalization of this phenomenon is going on. This process has always been and is slow. Living in the twenty-first century, we can observe how the world and its problems are becoming relevant to all. Therefore, the profession based on fullfledged support to an individual must adjust to the development of the world (Dirgèliené, 2013; Ivanauskiené \& Pakrijauskaité, 2015). However, in society, still there is no image on what are the limits of social worker's competences formed; therefore, social work is characterised quite unfavourably. A negative impact is rendered to social worker's prestige in society, constant facing with negative phenomena of life, undefined criteria for assessment of work results, large amounts of clients, overtime etc. (Kiaunytė, 2008). Influence of social work on society is low. Having compared different countries, quite high differences appear; they are determined by law, prevailing culture and economic opportunities of each of the countries.

In contemporary society, a certain stereotype that mass media are that social institute which is most trusted has formed. This means of information renders quite limited, stereotypical or negative information about the surrounding social reality, certain socio-cultural groups (Ališauskienè \& Markauskaite, 2014). However, mass media and their various forms make a biggest influence in formation of the status of the profession and when anchoring it among other professions. In mass media, the social work profession is usually depicted by presenting ambiguous information, emphasising drawbacks of social workers and discrepancies; information is presented without considering the image of the social work profession being shaped, and information itself is insufficiently detailed and clear. Despite that, mass media publish articles which form the image of a social worker which becomes a stereotype being positioned as representing societal attitude. Having explored the Western social context, it is obvious that society without services of social work professionals is unimaginable. This profession is treated as a profession of a modern society. Its contribution is enormous everywhere; nevertheless, in Lithuania it is insufficiently or unclearly perceived (Pivorienė \& Večerskytė, 2005; Varžinskienė, 2008; Kavaliauskienè, 2010; Wagner, 2014 etc.).

Problematic research issues. Observing information on the social worker's profession presented by mass media, an impression that society incompletely understands what functions are executed by representatives of this profession, what activities they are involved in and does society have sufficient information on social work at all appears. This supposes a problem research question related to perception and assessment of social work as a profession: Does society have sufficient information on the social worker's profession and its activities? 
The hypothesis: it is likely that society has no clear vision of what are the characteristics of the content of social worker's professional activities.

The object of the research is manifestation of the attitude towards the social worker's profession.

The aim of the research is to reveal manifestation of societal attitude towards the social worker's profession in Lithuania and the Ukraine.

Samples and methodology of the research. The research sample has been formed by applying the methods of non-probability and convenience sapling. The research sample was calculated on the ground of experience of the Public Opinion and Market Research Company Factus (2013), by carrying out quantitative research. The spreadsheet enabled finding out what sample of participants was required to obtain representative data. The survey involved 784 respondents from Lithuania ( $\mathrm{N}=416)$ and from the Ukraine $(\mathrm{N}=368)$. The questionnaire was applied to get the results of the research. Empirical data has been processed using the SPSS 17.0 (Statistical Package for Social Sciences). The descriptive statistical methods (means (M), standard deviations (SD), percentage, characteristics frequencies), a non-parametric independent sample Kruskal-Wallis $\mathrm{T}$ Test were applied. The results of the survey have been processed and analysed at significance level value $\mathrm{p} \leq 0.05$. The medians (M) are calculated with Anova test.

\section{The research results and discussion}

The content of social worker's professional activities in societal attitude. Analysis of this diagnostic field of characteristics of professional activities in social work aimed at finding out how much Lithuanian and Ukrainian respondents (hereinafter referred to as LT and UK) representing their societies are familiar with social work(see Table 1).

Table 1 Knowledge of social work respondents from Lithuania and the Ukraine $(\mathbf{N}=\mathbf{7 8 4})$

\begin{tabular}{|l|c|c|c|c|}
\hline \multirow{2}{*}{\multicolumn{1}{|c|}{ Structural parts }} & \multicolumn{2}{|c|}{ Lithuania (N=416) } & \multicolumn{2}{c|}{ the Ukraine (N=368) } \\
\cline { 2 - 5 } & $\mathbf{M}$ & $\mathbf{p}<\mathbf{0 . 0 5}$ & $\mathbf{M}$ & $\mathbf{p}<\mathbf{0 . 0 5}$ \\
\hline Social activities & $\mathbf{2 . 3 5}$ & 0.32 & 1.79 & 0.135 \\
\hline Caring for the sick & 2.09 & 0.37 & $\mathbf{2 . 5 3}$ & 0.063 \\
\hline House cleaning & $\mathbf{2 . 7 8}$ & 0.319 & $\mathbf{1 . 9 7}$ & 0.296 \\
\hline $\begin{array}{l}\text { Solution of different issues for } \\
\text { socially insecure families }\end{array}$ & 1.57 & $\mathbf{0 . 0 3 2}$ & 1.79 & 0.294 \\
\hline Charitable activities & $\mathbf{2 . 6 8}$ & $\mathbf{0 . 0 4 9}$ & 1.74 & 0.707 \\
\hline $\begin{array}{l}\text { Providing various services to } \\
\text { abandoned and people with } \\
\text { disabilities }\end{array}$ & 1.68 & 0.993 & 1.72 & $\mathbf{0 . 0 3 2}$ \\
\hline $\begin{array}{l}\text { Children's rights representation } \\
\text { problem families }\end{array}$ & 1.69 & 0.493 & 1.89 & $\mathbf{0 . 0 0 1}$ \\
\hline
\end{tabular}


Nemeikšienè \& Rüdytè, 2018. Manifestation of Societal Attitude Towards the Social Worker's Profession in Lithuania and the Ukraine

Lithuanian respondents regard social work as house cleaning $(\mathrm{M}=2.78)$ and charitable activities $(\mathrm{M}=2.68)$. Whereas the respondents from Ukraine claim that social work implies caring for the sick $(\mathrm{M}=2.53)$ and house cleaning $(\mathrm{M}=1.97)$. Few respondents mentioned activities that actually denote the field of social work such as solving issues of socially insecure families (LT M=1.57, UK M=1.79), providing various services to abandoned people and people with disability (LT $\mathrm{M}=1.68$, UK $\mathrm{M}=1.72$ ), children's rights representation problem families (LT $M=1.69$, UK $M=1.89$ ). The comparison of the responses given by the respondents from both countries implies that the respondents do not have a clearly delineated concept of social work and the functions they attribute to a welfare officer may also be performed by other professionals. The statistically significant difference $\left(x^{2}=53.685 a, d f=16, p=0.049\right)$ confirms the fact that Lithuanian respondents regard social work as charitable activities. Social work is not a highly-paid job; therefore, its reward is defined as a charity activity. Such attitude may be associated with the origin of this professional activity. Social work was being formed under the influence of the ideas of the social movement of early philanthropy and Christian church. Movements of charity organisations and community centres/homes are treated as direct prototypes of professional social work (Cox \& Pawar, 2013) successfully implementing their activities in presentday society, too. On the other hand, social work is characterised as paid professional activities aiming at helping people having serious problems in their lives by providing them with services of care and security as well as counselling and social support (Pierson \& Thomas, 2010). An assumption can be drawn that the formation of respondents' attitudes was influenced by the situation that social work is a little-paid professional activity; therefore, the associations with the profession's salaries name it charity work. The statistically significant difference in responses of Lithuanian respondents regarding the solution of different issues for socially insecure families $\left(\mathrm{x}^{2}=4.619, \mathrm{df}=1, \mathrm{p} \leq 0.032\right)$ as well as in answers given by the respondents from Ukraine about provision of various services to abandoned and people with disabilities $\left(\mathrm{x}^{2}=4.606, \mathrm{df}=1, \mathrm{p} \leq 0.032\right)$ and children's rights representation problem families $\left(\mathrm{x}^{2}=11.009, \mathrm{df}=1, \mathrm{p} \leq 0.001\right)$ signifies that social work in the mentioned fields has been better promoted/ is more familiar to the respondents.

The analysis of the research data has indicated other professionals being able to perform the duties of social workers (see Table 2).

The respondents from both countries chose a manager most often (LT $\mathrm{M}=3.14$; UK $\mathrm{M}=2.58$ ); they also thought that a police officer could implement the duties of social workers ( $\mathrm{LT} \mathrm{M}=2.78$; $\mathrm{UK} \mathrm{M}=2.28$ ) as well as a public figure (LT $\mathrm{M}=2.77$; UK $\mathrm{M}=2.11$ ). The statistically significant difference in dwelling places of the respondents and the choice of a police officer $\left(x^{2}=6.118, d f=2, p \leq 0.047\right)$ suggests that many respondents found professional functions of a social worker 
and police officer complimentary as one of the services a police officer provides is assisting people experiencing difficulties. There is a statistically significant difference in the responses of Ukrainian respondents regarding their dwelling places and professional choice of $a$ psychologist $\left(\mathrm{x}^{2}=8.925, \mathrm{df}=2, \mathrm{p} \leq 0.012\right)$ and social pedagogue $\left(\mathrm{x}^{2}=13.876, \mathrm{df}=2, \mathrm{p} \leq 0.001\right)$.

Table 2 Representatives of other professions who are able to perform functions of social workers from the point of view of Lithuanian and Ukrainian respondents $(\mathrm{N}=784)$

\begin{tabular}{|l|c|c|c|c|}
\hline \multirow{2}{*}{\multicolumn{1}{c|}{ Other professions }} & \multicolumn{2}{c|}{ Lithuania $\mathbf{( N = 4 1 6 )}$} & \multicolumn{2}{c|}{ the Ukraine (N=368) } \\
\cline { 2 - 5 } & $\mathbf{M}$ & $\mathbf{p}<\mathbf{0 . 0 5}$ & $\mathbf{M}$ & $\mathbf{p}<\mathbf{0 . 0 5}$ \\
\hline Health care professional & 2.26 & 0.191 & 1.94 & 0.515 \\
\hline Psychologist & 2.06 & 0.58 & 1.69 & $\mathbf{0 . 0 1 2}$ \\
\hline Educator & 2.20 & 0.527 & 1.84 & 0.135 \\
\hline Manager & $\mathbf{3 . 1 4}$ & 0.37 & $\mathbf{2 . 5 8}$ & 0.077 \\
\hline Police officer & $\mathbf{2 . 7 8}$ & $\mathbf{0 . 0 4 7}$ & $\mathbf{2 . 2 8}$ & 0.697 \\
\hline Social pedagogue & 1.61 & 0.215 & 1.54 & $\mathbf{0 . 0 0 1}$ \\
\hline Special educator & 2.00 & 0.128 & 1.81 & 0.476 \\
\hline Public figure & $\mathbf{2 . 7 7}$ & 0.607 & $\mathbf{2 . 1 1}$ & 0.972 \\
\hline
\end{tabular}

Working with clients of various ages, attributed to different social groups, a social worker performs many functions: analyses a particular situation, sets aims, plans, models, organises, coordinates, educates and teaches, consults, controls, defends human rights etc. (DuBois \& Miley, 2014; Hepworth et al., 2010; Максимов, 2015). Due to these diverse abundant functions attributed to a social worker, the corresponding professional roles of a social worker are singled out, such as mediator, defender, educator/teacher, changer of behaviour, consultant, service provider, case manager etc. (Hepworth et al., 2010). In professional performance of a social worker, these roles/functions are not separated; they usually are intertwined and a specialist must perform several roles of a social worker at once. Some functions performed by representatives of some professions actualised by the respondents are close to those being carried out by social workers (control, consulting, representation, formation of social skills etc.). An assumption can be drawn that the respondents mostly identify those social worker's functions which are mostly positioned in public space.

Socialworker's professional abilities, knowledge, value attitudes in the societal attitude. The profession of a social worker is acknowledged at an international level, and functions of this work must be performed by competent staff. Professional competence of a social worker may be characterised as a dynamic combination of knowledge, abilities and value attitudes contributing to professional authoritative solution of some issues and enabling proper performance of activities (Makštutytė \& Vaškevičiūtė, 2011). Each profession 
Nemeikšienè \& Rüdytè, 2018. Manifestation of Societal Attitude Towards the Social Worker's Profession in Lithuania and the Ukraine

requires a specific combination of competences; however, it is not easy to name and standardise professional competences of a social worker (Ruškus \& Kiaunytè, 2010). A social worker is a specialist whose work purpose is to enhance the abilities of man's adjustment to the surrounding environment, to restore relations with a community helping to integrate into society and stimulating full-fledged social functioning of an individual. Such complex activity requires not only specific knowledge on social work but also on other fields; this is acknowledged in specific spaces closely related to social work (scientific, academic, practical). The research aimed to find out what knowledge is required in professional activities of social work exactly from the point of view the respondents representing the general/ societal attitude (see Table 2). According to the results of the survey, both Lithuanian and Ukrainian respondents considered expertise in psychology the most significant in professional education (LT 95.6 percent; UK 96.5 percent), which implies that psychological background is vitally important in social work for professionals dealing with different socially disadvantaged groups of individuals (people with disabilities, social inadequacy, the homeless, etc.), in undefined and complex situations.

Table 3 Attitude of Lithuanian and Ukrainian respondents towards importance of knowledge required for a social worker $(\mathrm{N}=784)$

\begin{tabular}{|c|c|c|c|c|c|c|c|c|c|c|}
\hline \multirow{4}{*}{ 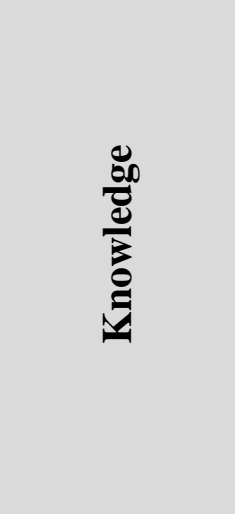 } & 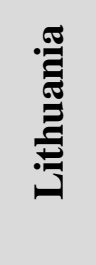 & 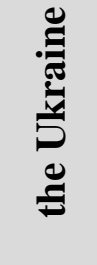 & 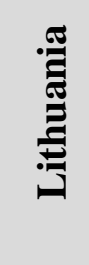 & 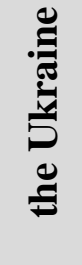 & & 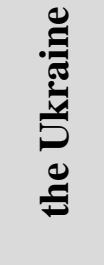 & 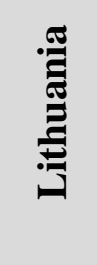 & 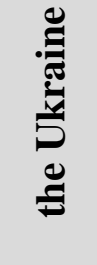 & \multirow{4}{*}{\multicolumn{2}{|c|}{$p<0.05$}} \\
\hline & Voc & ional & Sec & dary & & ege & $\begin{array}{r}\mathrm{Hi} \\
\mathrm{edu}\end{array}$ & $\begin{array}{l}\text { ter } \\
\text { tion }\end{array}$ & & \\
\hline & \multicolumn{8}{|c|}{ Accept } & & \\
\hline & \multicolumn{8}{|c|}{ Percentage } & & \\
\hline Legal & 73.5 & 58.6 & 42.5 & 88 & 33.4 & 70 & 44.7 & 79.8 & 0.004 & 0.000 \\
\hline $\begin{array}{l}\text { Psycholo- } \\
\text { gical }\end{array}$ & 89 & 98.4 & 95 & 100 & 100 & 91.4 & 100 & 94.7 & 0.000 & 0.096 \\
\hline Ethic & 86 & 86.7 & 90 & 100 & 97.4 & 72.9 & 97.1 & 82.9 & 0.000 & 0.046 \\
\hline Cultural & 84.4 & 81.4 & 85 & 84 & 91 & 81.4 & 90 & 81.5 & 0.022 & 0.005 \\
\hline Social policy & 81.3 & 81.4 & 85 & 42 & 89.8 & 74.1 & 82.1 & 80.6 & 0.026 & 0.343 \\
\hline Philosophy & 67.2 & 77.7 & 67.5 & 44 & 57.7 & 55.8 & 59 & 58.7 & 0.285 & 0.161 \\
\hline Sociology & 90.7 & 95.4 & 85 & 96 & 78.2 & 81.2 & 71 & 80.1 & 0.076 & 0.129 \\
\hline Management & 43.7 & 74.5 & 50 & 64 & 50 & 48.6 & 42 & 61.7 & 0.233 & 0.33 \\
\hline
\end{tabular}


The analysis of the survey results has indicated a statistically significant difference in attitudes towards the importance of expertise in social work (LT $\left.\mathrm{x}^{2}=94.554, \mathrm{df}=16, \mathrm{p} \leq 0.000\right)$. The respondents with college emphasised ethic expertise (LT 90.7 percent, $\mathrm{x}^{2}=79.146, \mathrm{df}=16, \mathrm{p} \leq 0.000$; UK 87.5 percent, $\left.\mathrm{x}^{2}=31.719, \mathrm{df}=20, \mathrm{p} \leq 0.046\right)$. The statistical significance $\left(\mathrm{LT} \mathrm{x}^{2}=23.300, \mathrm{df}=16\right.$, $\mathrm{p} \leq 0.022$; UK $\left.\mathrm{x}^{2}=40.292, \mathrm{df}=20, \mathrm{p} \leq 0.005\right)$ suggests cultural expertise being important. A social worker is expected to follow ethical guidelines, to respect different cultures and be sensitive to cultural differences as well as take care and provide social support to all national, religious and cultural minorities. The respondents also emphasised the importance of legal knowledge $\left(\mathrm{LT} \mathrm{x}^{2}=34.925\right.$, $\left.\mathrm{df}=16, \mathrm{p} \leq 0.004 ; \mathrm{UK} \mathrm{x}^{2}=53.012, \mathrm{df}=20, \mathrm{p} \leq 0.000\right)$ and expertise in social policy $\left(\mathrm{LT} \mathrm{x}^{2}=28.645, \mathrm{df}=16, \mathrm{p} \leq 0.026\right)$. Actualisation of knowledge in the areas of law and social policy allow drawing an assumption that the respondents identify the knowledge which is important to a social work relating this professional activity to the context of protection of human rights.

Table 4 Abilities required for a social worker in the attitude of Lithuanian and Ukrainian respondents $(\mathrm{N}=784)$

\begin{tabular}{|l|c|c|c|c|}
\hline \multirow{2}{*}{\multicolumn{1}{|c|}{ Skills }} & \multicolumn{2}{|c|}{ Lithuania (N=416) } & \multicolumn{2}{c|}{$\begin{array}{c}\text { the Ukraine } \\
\text { (N=368) }\end{array}$} \\
\cline { 2 - 5 } & $\mathbf{M}$ & $\mathbf{S D}$ & $\mathbf{M}$ & SD \\
\hline Entrepreneurship & $\mathbf{2 . 5 6}$ & 0.96 & $\mathbf{2 . 1 7}$ & 1.19 \\
\hline Project development and management & $\mathbf{2 . 3 0}$ & 0.93 & $\mathbf{2 . 0 3}$ & 1.12 \\
\hline Public activity & $\mathbf{1 . 9 2}$ & 0.84 & 1.90 & 1.04 \\
\hline Negotiating skills & 1.91 & 0.88 & 1.73 & 0.90 \\
\hline $\begin{array}{l}\text { The ability to organize human and } \\
\text { financial resources }\end{array}$ & 1.90 & 0.74 & $\mathbf{1 . 9 9}$ & 1.04 \\
\hline Self-evaluation and self-assessment & 1.87 & 0.79 & 1.84 & 1.01 \\
\hline The ability to use information technology & 1.77 & 0.75 & 1.72 & 0.90 \\
\hline Action research, analysis and evaluation & 1.74 & 0.75 & 1.62 & 0.84 \\
\hline Information analysis & 1.70 & 0.70 & 1.63 & 0.83 \\
\hline $\begin{array}{l}\text { The ability to influence the social } \\
\text { environment }\end{array}$ & 1.69 & 0.73 & 1.67 & 0.88 \\
\hline Ability to work independently & 1.52 & 0.67 & 1.64 & 0.93 \\
\hline $\begin{array}{l}\text { The ability to create a safe and } \\
\text { supportive environment }\end{array}$ & 1.52 & 0.65 & 1.68 & 0.88 \\
\hline Quick orientation & 1.48 & 0.60 & 1.53 & 0.82 \\
\hline Problem identification and resolution & 1.47 & 0.63 & 1.58 & 0.84 \\
\hline Communication & 1.44 & 0.63 & 1.47 & 0.71 \\
\hline $\begin{array}{l}\text { The ability to apply the knowledge } \\
\text { gained in practice }\end{array}$ & 1.41 & 0.55 & 1.46 & 0.75 \\
\hline The ability to care for others & 1.36 & 0.54 & 1.45 & 0.68 \\
\hline
\end{tabular}


Nemeikšienè \& Rüdytè, 2018. Manifestation of Societal Attitude Towards the Social Worker's Profession in Lithuania and the Ukraine

The aim of the research was to identify the most significant competences (skills) necessary in the field of social work (see Table 4).

The respondent from both countries claim that a social worker needs many skills from the list of common competences, i.e. entrepreneurship (LT M=2.56, UK $M=2.17$ ), project development and management (LT M=2.30, UK M=2.03), the ability to organize human and financial resources (UK M=1.99) as well as public activities (LT M=1.92). Nevertheless, the respondents from both countries did not find some other professional competences decisive and the following skills may be attributed to the latter: negotiating skills; capacity to investigate, analyse and access processes; ability to influence social environment; capability to identify and solve problems as well as looking after the others. The present fact implies that the respondents did not consider what skills certain competences include, whereas they acknowledged the ability of a welfare officer to realise their skills in practise.

Values of social workers constitute one of the most essential areas of professional competences, comprising a subjective fundamental of social work (Kavaliauskiene, 2010). As welfare offices deal with people from socially sensitive groups, it is vitally important for them to continually nourish their professional values as well as ethics in their personal and professional behaviour. The respondents were given a list of values defining the contents of communication between the client and welfare officer. There should be emphasised that assumptions of both Lithuanian and Ukrainian respondents were very alike (see Table 5).

Table 5 Social worker's professional values according to their importance in the attitude of Lithuanian and Ukrainian respondents $(\mathrm{N}=784)$

\begin{tabular}{|l|c|c|c|c|c|c|}
\hline \multirow{2}{*}{ Values } & \multicolumn{3}{|c|}{ Lithuania (N=416) } & \multicolumn{3}{c|}{ the Ukraine (N=368) } \\
\cline { 2 - 7 } & $\mathbf{M}$ & $\mathbf{S D}$ & $\mathbf{p}<\mathbf{0 . 0 5}$ & $\mathbf{M}$ & $\mathbf{S D}$ & $\mathbf{p}<\mathbf{0 . 0 5}$ \\
\hline $\begin{array}{l}\text { Customer's right to } \\
\text { choose }\end{array}$ & 2.06 & 0.84 & & 1.69 & 0.89 & \\
\hline Individualization & 2.04 & 0.87 & & 1.71 & 0.96 & \\
\hline Empowerment & 1.96 & 0.81 & & 1.74 & 0.96 & \\
\hline Acceptance & 1.83 & 0.81 & $\mathbf{0 . 0 0 0}$ & 1.69 & 0.96 & \\
\hline $\begin{array}{l}\text { Controlled emotional } \\
\text { involvement }\end{array}$ & 1.81 & 0.79 & & 1.62 & 0.89 & $\mathbf{0 . 0 2 2}$ \\
\hline Sharing knowledge & 1.71 & 0.72 & $\mathbf{0 . 0 2 2}$ & 1.70 & 0.90 & \\
\hline Social justice & 1.51 & 0.67 & & 1.56 & 0.82 & \\
\hline $\begin{array}{l}\text { The effort for the } \\
\text { customer }\end{array}$ & 1.51 & 0.64 & & 1.74 & 0.98 & \\
\hline Confidentiality & 1.46 & 0.74 & $\mathbf{0 . 0 4}$ & 1.43 & 0.78 & \\
\hline $\begin{array}{l}\text { Professional } \\
\text { responsibility }\end{array}$ & 1.44 & 0.61 & & 1.42 & 0.69 & \\
\hline
\end{tabular}


The respondents from both countries emphasised that all the listed values are important, however, some of them are more significant. Lithuanian respondents found choose (LT M=2.06), empowerment (LT M=1.96) and individualisation (LT M=2.04) essential. Ukrainians justified Lithuanian choices, however, complimented the list with efforts to help the client (UK $\mathrm{M}=1.74)$. The respondents consider that the possibility of choice to operate freely, assessing the current situation, like individualisation, empowerment, are important values; however, statistical significance has not been noticed. The analysis of the survey results with regards to the age of the respondents implies that the respondents from different countries distribute the values differently. The results of the research have revealed the statistically significant difference in attitudes towards the values complying with differences in age of the respondents. Lithuanian respondents from two different age groups (46-55 years old and above 56) found the value of knowledge sharing important (LT M=1.79, M=1.83), which is verified by the statistically significant difference between the variables and age groups $\left(\mathrm{x}^{2}=11.422, \mathrm{df}=4, \mathrm{p} \leq 0.022\right)$; therefore, one may assert that sharing professional knowledge with others as well as transferring personal experience is sensible and important to senior people. Ukrainian respondents from senior groups also emphasised the importance of this value (UK $M=1.80$ ), however, the statistically significant difference has not been identified in their case. Another value accentuated by two different age groups from Lithuania was the value of acceptance (aged 26-35 M=1.97; aged 46-55 M=1.99) which has been supported by the statistically significant difference $\left(x^{2}=20.161, d f=4, p \leq 0.000\right)$. Ukrainian respondent of senior age also expected social workers to accept all people despite their social backgrounds or cultural differences $(M=1.84, M=1.80)$. Lithuanian respondents did not find confidentiality very important, however, the importance of this value has been established by the statistically significant difference $\left(x^{2}=10.015, d f=4, p \leq 0.004\right)$. In regards to the different age groups, Lithuanian respondents did not accentuate the following values: social justice, professional responsibility or efforts to help the client. Aside from the afore mentioned values, in regards to the age groups, the respondents from both countries marked empowerment as an important value (LT aged 46-55 M=2.06, aged 36-45 $\mathrm{M}=1.98$; UK aged 36-45 $\mathrm{M}=1.75$, above $56 \mathrm{M}=2.0$ ). Ukrainian respondents from the youngest (under $25 \mathrm{M}=1.80$ ) and senior (above $56 \mathrm{M}=1.80$ ) groups accentuated the value of efforts to help the client, whereas among Lithuanian respondents this value was accentuated in the groups of young people (aged 26$35 \mathrm{M}=1.57$ ) and middle-aged (aged 46-55 $\mathrm{M}=1.58$ ). The value of controlled emotional involvement seemed to be important to Ukrainian respondents and this has been confirmed by the statistical difference $\left(x^{2}=11.476, d f=4, p \leq 0.022\right)$. In regards to the age groups, the respondents from both countries agreed that afore 
Nemeikšienè \& Rūdytè, 2018. Manifestation of Societal Attitude Towards the Social Worker's Profession in Lithuania and the Ukraine

mentioned values are important in communication or dealing with problems as well as establishing interpersonal relations.

\section{Conclusions}

On the ground of the performed empirical research, the following can be stated:

- Both in Lithuania and the Ukraine, respondents cannot exactly say what social work is; Lithuanian respondents give priority to charity and home clearing activities, whereas Ukrainian respondents emphasise that this means provision of various services to abandoned and people with disabilities as well as representation of child rights in problematic families.

- Respondents do not divide competences to general, professional or specialised. For them it is important that social workers would have such abilities which enable them to successfully realise themselves in professional activities. Respondents acknowledge the values of social work and treat them as important; however, respondents of both countries understand and single out different values as seen after comparing their age groups. According to age groups, Lithuanian respondents consider the following values as more important: acceptance, sharing of knowledge and confidentiality; whereas Ukrainian respondents emphasise controlled emotional involvement. To respondents' opinions, psychological preparation for this work is among most important ones because the staff must work with various groups of clients. Moreover, knowledge of ethical principles, cultural knowledge enable the workers to perform their duties better when working with various ethnical, religious and cultural minorities.

The hypothesis that it is likely that society has no clear vision on what are the characteristics of the content of professional activities of a social worker raised at the beginning of the paper has been only partly proven. The answers of the respondents suggest that they do not know what social work is; but they identify certain content/functions of social worker's professional activities. They do not single out professional competences; however, they name the knowledge, abilities which are required for a social worker. They understand the values which are not attributed to general values but rather particularly oriented to a client, and know real material condition of a social worker, i.e. that this job is low paid. 


\section{References}

Ališauskienė, M., \& Markauskaitė, G. (2014). Religinès ịvairovès reprezentavimas Lietuvos internetinèje žiniasklaidoje. Kultūra ir visuomenè, 5 (1), 65-83.

Cox, D., \& Pawar, M. (2013). International social work: issues, strategies, and programs. Los Angeles; London: Sage.

Dirgèlienè, I. (2013). Profesinio streso rizika socialinio darbo procese: supervizijos taikymo perspektyva. Sveikatos mokslai, 1, 31-36.

DuBois, B., \& Miley, K. K. (2014). Social work: an empowering profession. Boston: Pearson.

Hepworth, D. H., Rooney, R. H., Rooney, G. D., Strom-Gottfried, K., \& Larsen, J. (2010). Direct social work practice. Theory and Skills. USA: Brooks/Cole, Cengage Learning.

Ivanauskienè, V., \& Pakrijauskaité, A. (2015). Tarptautinio socialinio darbo ypatumai: socialinès pagalbos teikejjų pabėgèliams ir prieglobsčio prašytojams Lietuvoje bei Švedijoje požiūris. Tiltai, 1, 141-155.

Kavaliauskienè, V. (2010). Refleksijos kultūra - socialinio darbuotojo profesinès veiklos raiškos aspektas. Acta Paedagogica Vilnensia, 25, 159-171.

Kiaunytè, A. (2008). Pokyčius patiriantys socialiniai darbuotojai: supervizijos taikymo galimybès. Socialinis darbas, 7 (2), 119-130.

Makštutytè, R., \& Vaškevičiūtè, L. (2011). Socialinio darbuotojo profesionalumas komunikacinès kompetencijos aspektu. Socialinis darbas. Patirtis ir metodai, 8 (2), 23-37.

Pierson, J., \& Thomas, M. (2010). Dictionary of social work: the definitive A to Z of social works and social care.Maidenhead: McGraw-Hill.

Pivorienė, J., \& Večerskytė, J. (2005). Socialinio darbo įvaizdis interneto svetainèse. Socialinis darbas, 4 (2), 132-141.

Public Opinion and Market Research Company Factus (2013). Downloaded from: http://www.factus.lt/main-calculator

Ruškus, J., \& Kiaunyte, A. (2010). Socialinių darbuotojų elgsenos modelių identifikavimas sprendžiant profesinius konfliktus. Filosofija. Sociologija, 2, 112-121.

Varžinskienè, L. (2008). Socialinio darbo profesijos statuso ypatumai socialinių darbuotojų ir jų partnerių požiūriu. Socialinis darbas, 7 (1), 100-107.

Wagner, H. (2014). Socialinio darbo profesijos (ne)galia visuomenèje. STEPP: socialine teorija, empirija, politika ir praktika, 9, 7-20.

Максимов, Е. К. (2015). Концепция социальной работы с персоналом в современных условиях. Интернет-журнал «Науковедение», 7 (2), 1-16. Downloaded from: http://naukovedenie.ru/PDF/35EVN215.pdf 